\title{
DESIGN, MANUFACTURING AND TESTING OF SHELL AND TUBE HEAT EXCHANGER AND TO COMPARE THE PERFORMANCE USING PLAIN TUBES AND LOWFIN TUBES
}

\author{
Harish $\mathbf{R}^{1}$, Santosh Ghorpade ${ }^{2}$, Rudragouda R Patil ${ }^{3}$, V. Santoshkumar ${ }^{4}$ \\ ${ }^{1}$ Assistant Professor, Department of Mechanical Engineering, JITS.Narsampet, TS, INDIA \\ ${ }^{2}$ Assistant Professor Department of Mechanical Engineering, JITS.Narsampet, TS, INDIA \\ ${ }^{3}$ Research scholar, Department of Mechanical Engineering JJTU. Jhunjhunu, Rajasthan, INDIA \\ ${ }^{4}$ Research scholar, Department of Mechanical Engineering JJTU. Jhunjhunu, Rajasthan, INDIA
}

\begin{abstract}
The project aim is to provide an overview of design, manufacture and testing of shell and tube heat exchanger and to compare the performance with using plain tube and low fin tubes. The objective of the project is to remove the heat from the lubricating oil passing it through the heat exchanger where in a coolant is circulated to remove the heat. Water is commonly used as the coolant to dissipate heat. The heat exchangers are designed for shell side flow rate $35 \mathrm{lpm}$, temperature $55^{\circ} \mathrm{C}-45^{\circ} \mathrm{C}$ and tube side flow rate of $30^{\circ} \mathrm{C}-35^{\circ} \mathrm{C}$. First the design calculations are done using the details of heat exchanger, various correlations and finally arriving at the design drawing of heat exchanger using the AutoCAD tool. Various manufacturing techniques were used for manufacturing of heat exchanger. Testing was then done on the manufactured heat exchangers for checking the performance of the heat exchangers.
\end{abstract}

Keywords: - Plain Tube, Low Fin Tube, Shell And Tube Heat Exchanger.

$* * *$

\section{INTRODUCTION}

Heat exchanger is a device which transfers energy from one fluid to another fluid across a solid surface. Exchanger analysis and design therefore involve both conduction and convection. Heat exchangers are used in a wide variety of engineering applications like power generation, waste heat recovery, manufacturing industry, air-conditioning, refrigeration, space applications, petrochemical industries etc.

Two important problems in heat exchanger analysis are:

- Rating existing heat exchangers: rating involves determination of the rate of heat transfer, the change in temperature of the two fluids and pressure drop across the heat exchanger.

- Sizing the heat exchanger for particular application: sizing involves selection of a specific heat exchanger from currently available or determining the dimensions for the design of a new heat exchanger, given the required rate of heat transfer and allowable pressure drop.

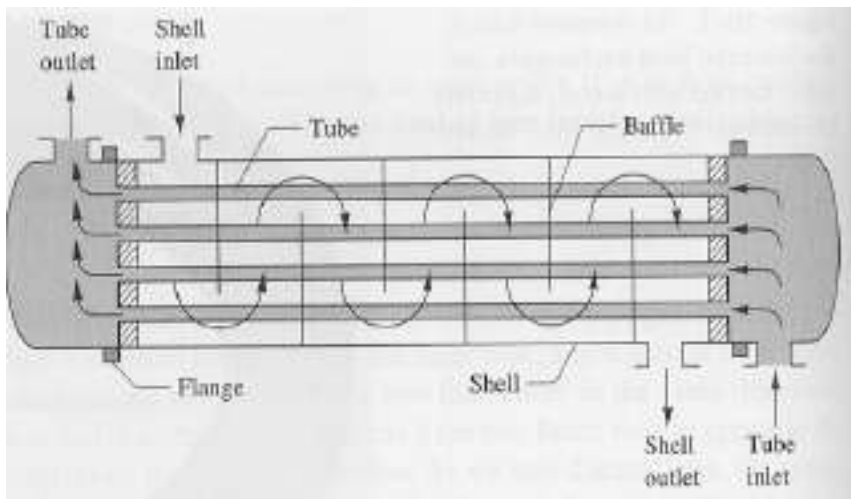

Fig 1.1: Single pass shell and tube heat exchanger

Shell and tube heat exchangers are most versatile type of heat exchanger. They are used in process industries, in conventional and nuclear power station as condenser, in steam generators in pressurized water reactor power plants, in feed water heaters and in some air conditioning refrigeration systems. Shell and tube heat exchanger provide relatively large ratio of heat transfer area to volume and weight and they can be easily cleaned. Shell and tube heat exchanger offer great flexibility to meet almost any service requirement. Shell and tube heat exchanger can be designed for high pressure relative to the environment and high pressure difference between the fluid streams. 


\subsection{Shell and Tube Heat Exchanger Geometry}

The standard of the Tubular Exchanger Manufacturers Association (TEMA) describe various components in detail of shell and tube heat exchanger (STHE).

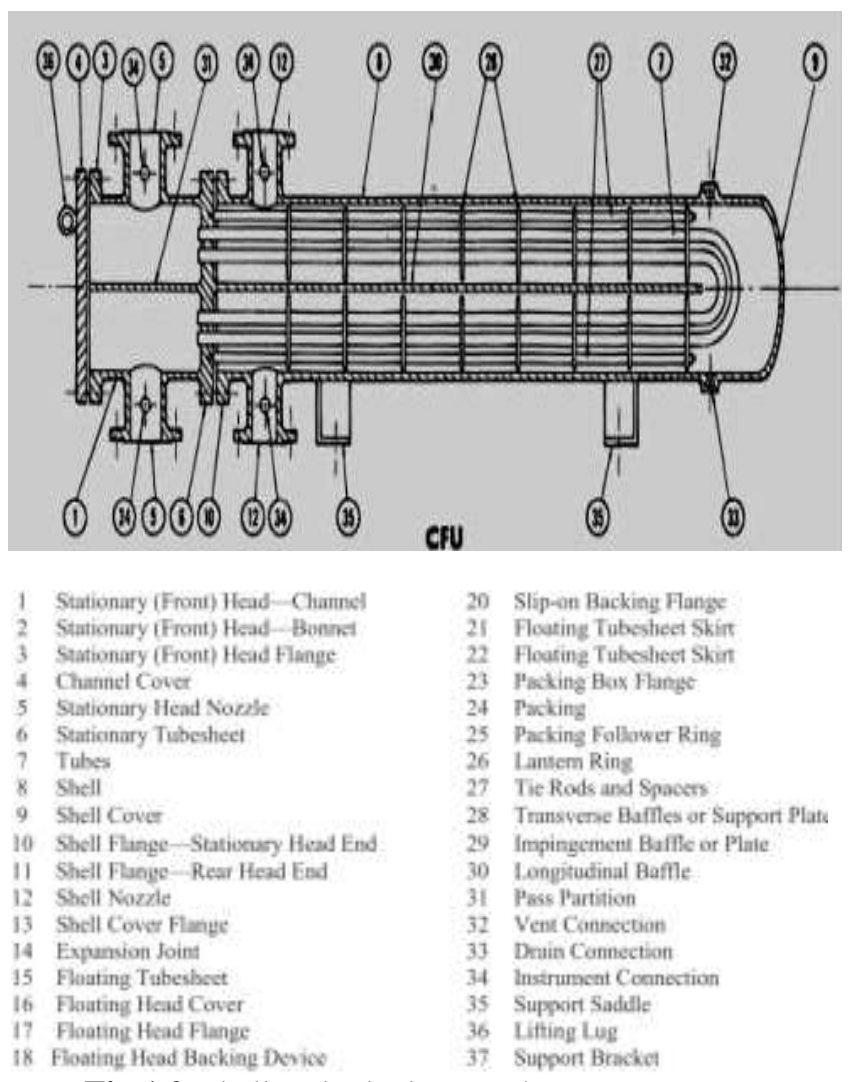

Fig 1.2: shell and tube heat exchanger geometry

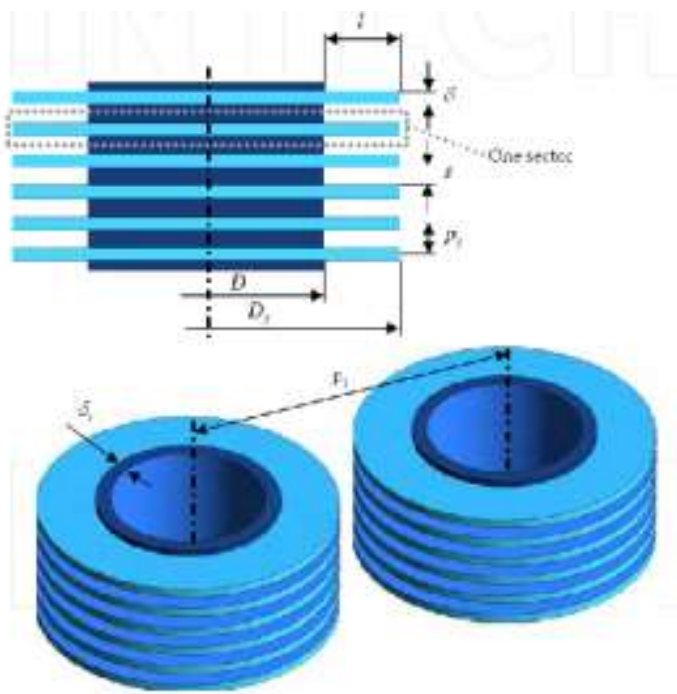

Fig 1.3: Fin tube geometry

\section{Design Formulas used for Calculation}

\begin{tabular}{|c|c|c|}
\hline $\begin{array}{l}\text { Paramete } \\
\text { rs }\end{array}$ & $\begin{array}{l}\text { Low fin tube heat } \\
\text { exchanger }\end{array}$ & $\begin{array}{l}\text { Plain tube heat } \\
\text { exchanger }\end{array}$ \\
\hline $\begin{array}{l}\text { Mass flow } \\
\text { rate in lpm }\end{array}$ & $m * C_{p} * \triangle T$ & $m * C_{p} * \triangle T$ \\
\hline LMTD & $\begin{array}{l}\text { LMTD } \\
=\frac{\left(T_{1}-t_{2}\right)-\left(T_{2}-t_{1}\right.}{\ln \left[\frac{T_{1}-t_{2}}{T_{2}-t_{1}}\right]}\end{array}$ & $\begin{array}{l}\text { LMTD } \\
=\frac{\left(T_{1}-t_{2}\right)-\left(T_{2}-t_{1}\right.}{\ln \left[\frac{T_{1}-t_{2}}{T_{2}-t_{1}}\right]}\end{array}$ \\
\hline $\begin{array}{l}\text { Heat } \\
\text { transfer } \\
\text { coefficient }\end{array}$ & $\begin{array}{l}N u \\
=0.183 \\
* 46500.44^{0.7} \\
*\left[\frac{0.7}{0.8}\right]^{0.36} \\
*\left[\frac{0.02}{0.016}\right]^{0.06} \\
*\left[\frac{0.8}{16}\right]^{0.11} \\
* 0.446^{0.36}\end{array}$ & $\begin{array}{l}N u \\
=0.023 * R_{e}^{0.8} \\
* P^{0.4}\end{array}$ \\
\hline $\begin{array}{l}\text { Pressure } \\
\text { drop }\end{array}$ & $\begin{array}{l}\Delta P_{t} \\
=\left[\frac{4 f l N_{p}}{D_{i}}+4 N_{p}\right] \\
* \frac{\rho * u^{2}}{2}\end{array}$ & $\begin{array}{l}\Delta P_{t} \\
=\left[\frac{4 f l N_{p}}{D_{i}}+4 N_{p}\right] \\
* \frac{\rho * u^{2}}{2}\end{array}$ \\
\hline $\begin{array}{l}\text { Surface } \\
\text { area of } \\
\text { fins }\end{array}$ & $\begin{array}{l}A_{f} \\
=\left\{\frac{1}{2} * \pi\left(D_{f}^{2}-D^{2}\right)\right. \\
\left.+\pi * D_{f} * \delta\right\} * F P I\end{array}$ & $A=\pi * d * l * n$ \\
\hline $\begin{array}{l}\text { Total tube } \\
\text { surface } \\
\text { with fin } \\
\text { removed: }\end{array}$ & $\begin{array}{l}A_{t} \\
=\left\{\pi * D_{f} *(s+\delta)\right\} \\
* F P I\end{array}$ & $A=\pi * d * l * n$ \\
\hline $\begin{array}{l}\text { Overall } \\
\text { heat } \\
\text { transfer } \\
\text { coefficient }\end{array}$ & $\begin{array}{l}\frac{1}{U_{o f}} \\
=\frac{1}{h_{o}}+\frac{D_{o}}{2 k} \ln \left(\frac{D_{0}}{D_{i}}\right) \\
+\frac{A_{0}}{A_{i}} \eta_{\text {eff }}\left(\frac{1}{h_{i}}\right)\end{array}$ & $\frac{1}{U}=\frac{1}{h}+\frac{1}{h_{0}}$ \\
\hline
\end{tabular}

Details of Low Finned Tube and Plain Tube Heat Exchanger

\begin{tabular}{|l|l|l|}
\hline Parameter & Low finned tube & Plain tube \\
\hline Shell Diameter & $164 \mathrm{~mm}$ & $164 \mathrm{~mm}$ \\
\hline Shell length & $850 \mathrm{~mm}$ & $850 \mathrm{~mm}$ \\
\hline Tube diameter & $\begin{array}{l}16 \mathrm{~mm} \mathrm{OD} \times 12.8 \\
\mathrm{~mm} \mathrm{ID}\end{array}$ & $\begin{array}{l}16 \mathrm{~mm} \text { OD } \times \\
14 \mathrm{~mm} \text { ID }\end{array}$ \\
\hline Number of tubes & 24 & 24 \\
\hline Tube pitch & $20 \mathrm{~mm}$ & $20 \mathrm{~mm}$ \\
\hline $\begin{array}{l}\text { Type of tube } \\
\text { layout }\end{array}$ & Triangular & Triangular \\
\hline $\begin{array}{l}\text { Number of } \\
\text { baffles }\end{array}$ & 19 & 19 \\
\hline
\end{tabular}




\section{MANUFACTURING}

All the parts required for the manufacture of a shell and tube heat exchanger are obtained. The different parts include the shell, tubes, tube plates, nozzles, end covers, BSP collar, and baffle plates are manufactured by different manufacturing processes.

\subsection{Manufactured Parts}

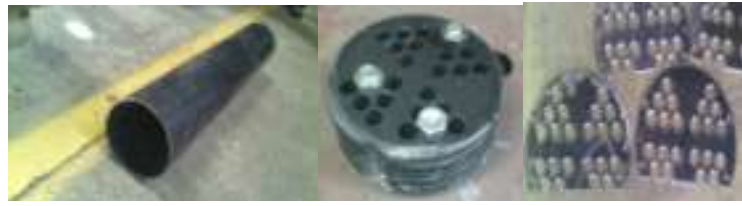

Shell cut part, baffle plates and baffle cut parts

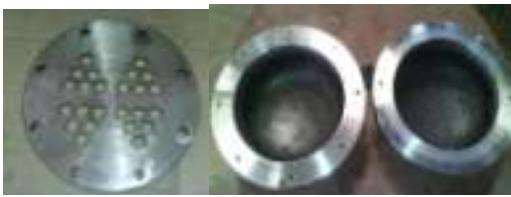

Tube plate and end covers

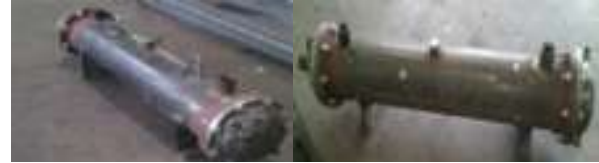

shell and tube heat exchanger after assembly

\subsection{Materials Used}

Shell: Mild steel, Tube: Copper- nickel

Tube Plate: Mild steel, Baffles: Mild steel

Nozzles: mild steel, Gasket: Compressed asbestos fiber

\section{EXPERIMENTATION}

Testing is one of the most crucial stages of the project. In this stage the performance of the designed heat exchanger is evaluated.

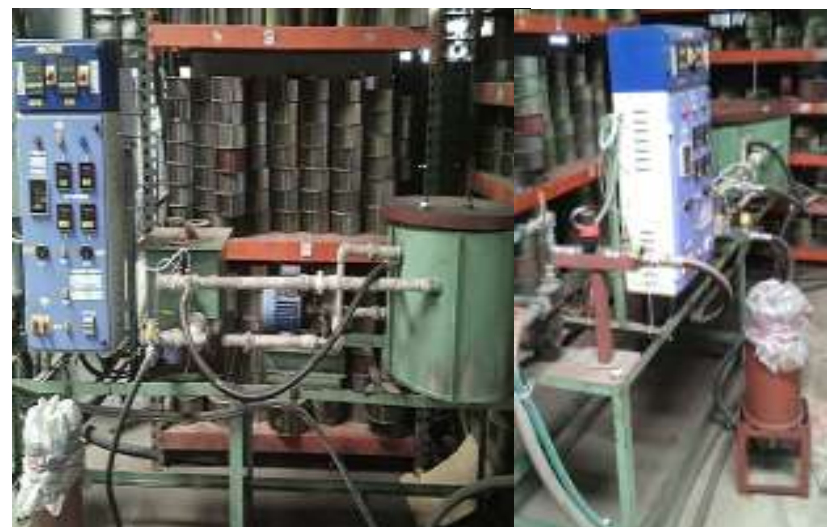

Experimental setup

Make the connections of shell and tube heat exchanger. Turn on the main power and turn on hot and cold fluids supply all the way. Set the inlet oil temp to $55^{\circ} \mathrm{C}$ and water flow rate to $20 \mathrm{lpm}$. Fix the inlet oil flow rate $15 \mathrm{lpm}$. Wait for at least 15 minutes so that the system reaches steady state. Note down the readings of outlet temperatures of oil and water. Repeat the procedure for oil flow rates of 20, 25, 30 and $35 \mathrm{lpm}$.

\subsection{Experimental Capabilities}

- Effect of counter current flow

- Overall heat balance

- Determination of liquid/liquid heat transfer coefficients.

- Influence of flow rate on heat transfer coefficients

- Comparison of LMTD for different inlet temperature and flow rates of oil.

Water and oil (ISO VG46) is used in all experiments but performance characteristics using other fluids can also be investigated.

\subsection{Equipment Specifications}

Both plain tube and low fin tube heat exchangers having the same dimensions.

- Shell diameter

- Shell length : $\quad 164 \mathrm{~mm}$

$: 850 \mathrm{~mm}$

- Number of tubes : $\quad 24$

\section{RESULTS AND DISCUSSIONS}

\subsection{Effect of Flow Rate of Hot Fluid (Oil)}

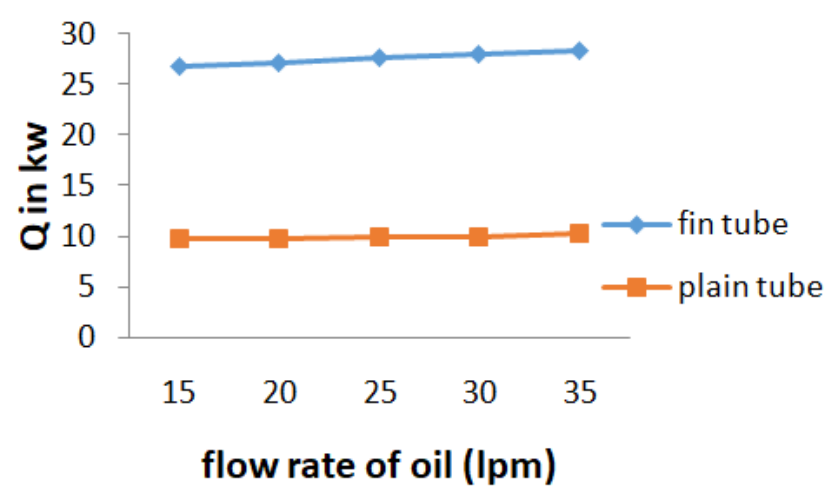

Fig 4.1: Flow rate of oil V/S heat load

As the flow rate of oil increases the heat transfer rate also increases which in turn increases the overall heat 1 transfer coefficient. This is because increase in oil flow ratelincreases the Reynolds number which in turn increases the overall heat1transfer coefficient and also decreases the outlet temperature of oil.

From figure observed that as the flow rate of oil varied from 15 to $35 \mathrm{lpm}$ the heat transfer rate in low fin tube heat exchanger increases from 26.7 to $28.3 \mathrm{kw}$ and in plain tube heat exchanger it increases from $9.7 \mathrm{kw}$ to $10.13 \mathrm{kw}$. Also from the figure it is seen that for the designed value $351 \mathrm{pm}$ of oil flow rate heat exchanger with plain tube is giving heat transfer rate of $10.13 \mathrm{kw}$ and heat exchanger with low fin tubes giving the heat transfer rate of $28.3 \mathrm{kw}$. 


\subsection{Effect of Flow Rate of the Cold Fluid (Water)}

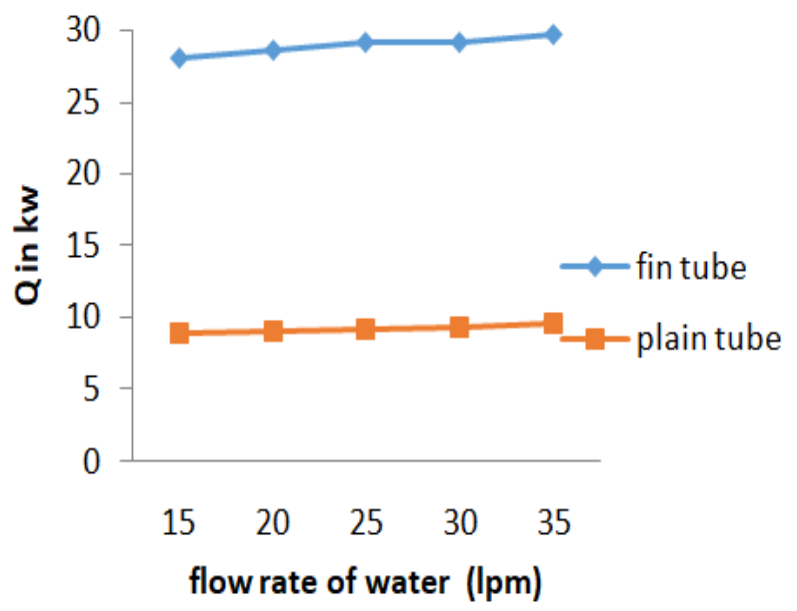

Fig 4.2: Flow rate of water $\mathrm{V} / \mathrm{S}$ heat load

As from figure in STHE having plain tubes the1 heat transfer rate is increasing from $8.5 \mathrm{kw}$ to $9.9 \mathrm{kw}$ whereas in STHE having low fin tubes, the1heat transfer1rate is increases from $28.14 \mathrm{kw}$ to $29.85 \mathrm{kw}$. Also from the figure it is seen that for the designed value $35 \mathrm{lpm}$ of oil flow rate heat exchanger with plain tube is giving heat transfer rate of $9.9 \mathrm{kw}$ and heat exchanger with low fin tubes giving the heat transfer rate of $29.85 \mathrm{kw}$.

\subsection{Effect of Inlet Oil Temperature}

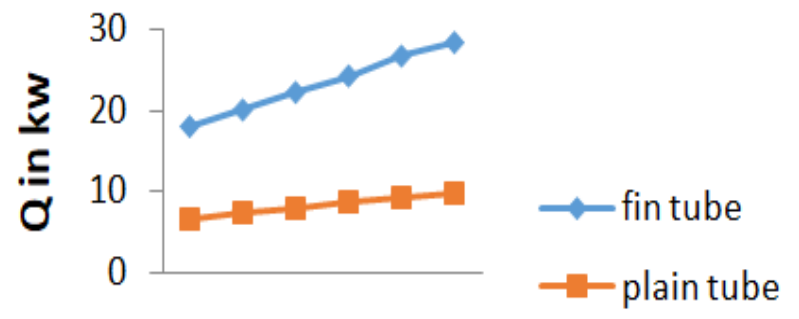

454749515355

\section{Inlet oil temp $\left({ }^{\circ} \mathrm{C}\right)$}

Fig 4.3: Intel oil temperature V/S heat load

From fig, heat1exchanger having low fin tubes increases the heat 1 transfer rate from $17.8 \mathrm{kw}$ to $28.2 \mathrm{kw}$ whereas heat exchanger having plain tubes increases the heat transfer rate from $6.65 \mathrm{kw}$ to $9.8 \mathrm{kw}$ for the same inlet oil temperature variation. Also from the figure it is seen that for the designed value of inlet oil temperature $55^{\circ} \mathrm{C}$ to $45{ }^{\circ} \mathrm{C}$ the heat exchanger with plain tube is giving heat transfer rate of $9.8 \mathrm{kw}$ and the heat exchanger with low fin tubes giving the heat transfer rate of $28.2 \mathrm{kw}$.Fin tube heat exchanger giving more heat transfer rate than plain tube heat exchanger as shown in figure.

\subsection{Effect of Pressure Drop of Oil}

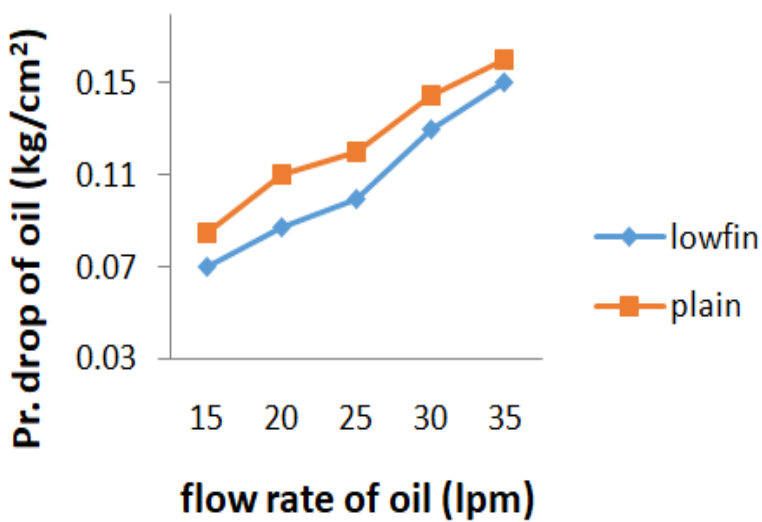

Fig 4.4: Flow rate of oil V/S pressure drop

The flow rate of oil varied from $151 \mathrm{pm}$ to $351 \mathrm{pm}$ pressure drop of shell side fluid in case of plain1tube STHE is from 0.085 to $0.16 \mathrm{~kg} / \mathrm{cm}^{2}$ whereas in low finltube STHE the pressure drop is from 0.07 to $0.15 \mathrm{~kg} / \mathrm{cm}^{2}$

\subsection{Effect of Pressure Drop of Water}

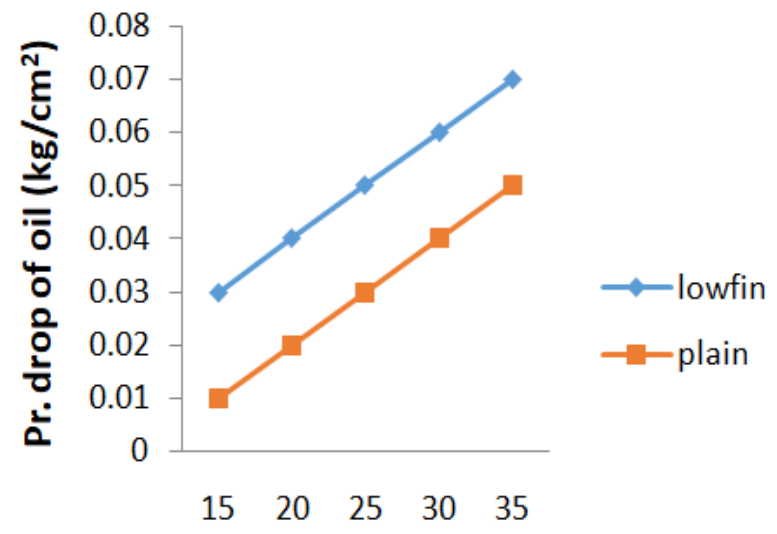

Flow rate of water (Ipm)

Fig 4.5: Flow rate of water V/S Pressure drop

An increase in the pressure1drop with increase in fluid flow1rate in shell and1tube heat exchanger which increases the pumping1power. From figure with increase in 1 the flow rate of water increasing the pressure drop in tube side. The water flow1rate is varied from $151 \mathrm{pm}$ to $35 \mathrm{lpm}$ the pressure drop1of water in tube side in case of plain1tube is from 0.01 to $0.05 \mathrm{~kg} / \mathrm{cm}^{2}$ whereas in case of low fin 1 tube STHE varies from 0.03 to $0.07 \mathrm{~kg} / \mathrm{cm}^{2}$.

\section{CONCLUSION}

From study the following conclusions are. Observed that as the flow rate of oil increased the amount of heat dissipated is more. As the flow1rate of water is increased1the amount of heat dissipated is more. As the inlet oil temperature is reduced the amount of heat transferred from oil is less. Varying the flow rate1 of oil, the plain tubelheat exchanger 
giving more shell side pressure drop compared to heat exchanger having low fin tubes. Varying the flow rate of water, the low fin tube heat exchangers giving 1.2 to 1.5 times better tube side pressure drop than the heat exchanger having plain tubes.

Hence, with the increase in heat transfer area in heat exchanger thelheat transfer rate is more. Shell and tubelheat exchanger having low fin tube is giving almost 3 times better result in all three possible cases than the heat exchanger having plain tube.

\section{REFERENCES}

[1] M. Thirumarimurugan, T.Kannadasan and E.Ramasamy, "Performance Analysis of Shell and Tube Heat Exchanger Using Miscible System".

[2] Sandeep K. Patel, Professor Alkesh M. Mavani, "Shell \& tube heat exchanger thermal designwith optimization of mass flow rate".

[3] Ankith R. Patel, "Design and Optimization of shelland-tube heat exchanger", Indian journal of applied research, Aug 2013 ISSN - 2249-555X

[4] Igor Wolf, Bernard Franković, Ivan Viličić ,RomualdJurkowski, André Bailly, "A numerical and experimental analysis of heat transfer in a wavy finand-tube heat exchanger".

[5] Y.B. Tao, Y.L. He, J. Huang, Z.G. Wu, W.Q. Tao, "Numerical study of local heat transfer coefficient and fin efficiency of wavy fin-and-tube heat exchangers".

[6] M. V. Ghori\& R. K. Kirar, "Numerical Analysis of Tube-Fin Heat Exchanger using Fluent".

[7] Shiv Kumar Rathore, AjeetBergaley, "Comparative analysis of finned tube and bared tube type shell and tube heat exchanger". 